\title{
DYSREGULATION OF TEMPERATURE AND LIVER CYTOKINE GENE EXPRESSION IN IMIMUNODEFICIENT WASTED MICE
}

\author{
Claudia R. Libertin ${ }^{* \dagger}$, Lydia Ling-Indeck", Paul Weaver*, \\ Chin-Mei Chang-Liu ${ }^{\ddagger}$, Vesna Strezoska ${ }^{\ddagger}$,Barbara Heckert ${ }^{\ddagger}$, \\ and Gayle E. Woloschak ${ }^{* \ddagger}$
}

*Department of Pathology, ${ }^{\dagger}$ Department of Medicine

Loyola University Medical Center

2160 S. First Ave.

Maywood, IL 60153

${ }^{\ddagger}$ Center for Mechanistic Biology and Biotechnology

Argonne National Laboratory

9700 Cass Ave.

Argonne, IL 60439

Running Title: Temperature/Cytokine Dysregulation in Wasted Mice

Address Correspondence to:

Gayle E. Woloschak

Argonne National Laboratory

Center for Mechanistic Biology and Biotechnology

9700 South Cass Avenue

Argonne, Illinois 60439-4833

Phone (708) 252-3312

Fax (708) 252-3387

Key Words: immunodeficiency; wasted mice; cytokine; DNA repair; temperature dysregulation 


\begin{abstract}
Wasted mice bear the spontaneous autosomal recessive mutation wst/wst; this genotype is associated with weight loss beginning at 21 days of age, neurologic dysfunction, immunodeficiency at mucosal sites, and increased sensitivity to the killing effects of ionizing radiation. The pathology underlying the disease symptoms is unknown. Experiments reported here were designed to examine thermoregulation and liver expression of specific cytokines in wasted mice and in littermate and parental controls. Our experiments found that wasted mice begin to show a drop in body temperature at 21-23 days following birth, continuing until death at the age of 28 days. Concomitant with that, livers from wasted mice expressed increased amounts of mRNAs specific for cytokines IL-6 and IL-1, the acute phase reactant C-reactive protein, c-jun, and apoptosis-associated $\mathrm{Rp}-8$ when compared to littermate and parental control animals. Levels of $\beta$-transforming growth factor (TGF), c-fos, proliferating cell nuclear antigen (PCNA), and ornithine amino transferase (OAT) transcripts were the same in livers from wasted mice and controls. These results suggest a relationship between an acute phase reactant response in wasted mice and temperature dysregulation.
\end{abstract}

\title{
DISCLAIMER
}

This report was prepared as an account of work sponsored by an agency of the United States Government. Neither the United States Government nor any agency thereof, nor any of their employees, makes any warranty, express or implied, or assumes any legal liability or responsibility for the accuracy, completeness, or usefulness of any information, apparatus, product, or process disclosed, or represents that its use would not infringe privately owned rights. Reference herein to any specific commercial product, process, or service by trade name, trademark, manufacturer, or otherwise does not necessarily constitute or imply its endorsement, recommendation, or favoring by the United States Government or any agency thereof. The views and opinions of authors expressed herein do not necessarily state or reflect those of the United States Government or any agency thereof. 


\section{INTRODUCTION}

Mice bearing the autosomal recessive gene wst/wst develop a series of abnormalities that included weight loss, neurologic dysfunction, and immunodeficiency, all of which are evident in the mice as early as 21 days of age (1-4). Lymphocytes from these mice also manifest an increased sensitivity to the killing effects of ionizing radiation (5) and enhanced radiation-induced apoptosis (Woloschak et al., unpublished information). Recent studies from our group have determined that the weight loss in these mice is associated with a threefold reduction in liver expression of albumin, while expression of other liver-specific transcripts (tumor necrosis factor, metallothionein, and others) remains unchanged $(6,7)$.

Work by other groups has shown that IL6 and IL1 are positive mediators of the liver acute phase reaction proteins (such as C-reactive protein), negative mediators of body temperature, and negative mediators of albumin gene expression $(8,9)$. In addition, recent studies have documented that increased expression of cjun, IL6, and Rp-8 are associated with induction of the apoptotic pathway in a variety of different cell types, including liver cells $(10,11)$. In the work reported here, we examined body thermoregulation and liver-specific gene expression in wasted mice. Our studies demonstrated increased expression of IL6, IL1, Creactive protein, $c-j u n$, and $R p-8$ transcripts in livers from wasted mice relative to controls. Concomitantly, wasted mice also showed a drop in body temperature first evident at 21-23 days of age, with a continued decline until death at 28 days of age. These results suggest an association between abnormal liver cytokine 
expression and thermodysregulation, and they also suggest a role for these factors in the pathogenesis of the wasted mouse abnormalities.

\section{MATERIALS AND METHODS}

Mice

The wst / wst mice were bred in the sterile, hooded animal facility in the Center for Mechanistic Biology and Biotechnology at Argonne National Laboratory from $w s t /+$ breeding pairs obtained from the Jackson Laboratory (Bar Harbor, ME). Because the wasted trait is inherited as an autosomal recessive disorder, approximately $25 \%$ of the animals in each litter can be diagnosed (by neurologic examination) as having the syndrome. The remainder of the litter appears normal. Normal littermates of $w s t / w s t$ mice are labeled $w s t /$. These $w s t / \cdot$ mice should be a mixture of $67 \% w s t /+$ and $33 \%+/+$; they serve as age-matched controls. All results reported here are for animals 22-28 days of age. For each experiment, livers from 3-5 animals (mixed male and female) were pooled. Preliminary experiments have not shown differences between male and female mice or between individual animals.

Previous work from our laboratory has suggested that $w s t / \cdot$ mice may not be totally normal (2, 3, 5-7; Woloschak et al., unpublished information). Therefore, as an additional control, we included $\mathrm{BCF}_{1}$ mice (C57BL6 $\times \mathrm{C} 3 \mathrm{H} / \mathrm{HeN} \mathrm{F}_{1}$ ) bred in the same animal facility at Argonne. All $\mathrm{BCF}_{1}$ mice were age-matched (within 2 days) with $w s t / w s t$ mice within a single experiment. This mouse strain was chosen as a control because it is the parental strain from which wst mice were 
derived (1) and is designated in this work as the parental control. Mice were given a nonpurified diet (Purina Laboratory Chow, Cincinnati, $\mathrm{OH}$ ) ad libitum. All mice were killed by cervical dislocation; tissues were harvested and stored at $-70^{\circ} \mathrm{C}$ before use.

All animal treatments were approved by Argonne National Laboratory Animal Care and Use Committee prior to implementation.

Temperature determinations. Daily rectal temperatures were taken between 10 a.m. and noon on wst/wst mice, and littermates from a single litter were individually housed beginning at day 18 of age. During this time, the body temperatures of wst/wst mice dropped from $36.5^{\circ} \mathrm{C}$ to $34.5^{\circ} \mathrm{C}$. It is likely that huddling in a litter is required for maintenance of body temperature during this time interval; animals that failed to do so died.

$m R N A$ Preparation. Frozen tissues were thawed in homogenization buffer $(0.075$ $\mathrm{mol} / \mathrm{L}$ sodium chloride, $0.025 \mathrm{~mol} / \mathrm{L}$ disodium EDTA, $0.02 \mathrm{~mol} / \mathrm{L}$ Tris, $\mathrm{pH} 8.0$, and $0.5 \mathrm{~g} / \mathrm{L}$ sodium dodecyl sulfate) and homogenized in a Waring blender with an equal volume of fresh phenol. Following phenol extraction, samples were precipitated from ethanol overnight at $-20^{\circ} \mathrm{C}$. The pellet was dissolved in water and RNA was precipitated from $3 \mathrm{~mol} / \mathrm{L}$ sodium acetate $(\mathrm{pH} 6.0)$ for $2 \mathrm{~h}$ at $4^{\circ} \mathrm{C}$. Poly $\mathrm{A}+\mathrm{RNA}$ was separated from total RNA using oligodeoxythymidylate affinity column chromatography. mRNA was quantitated by monitoring absorbance at $260 \mathrm{~nm}$ (6, $7,12)$. 
mRNA Northern Blots and Hybridizations. Northern blots were performed as described previously (12). Prior to hybridization, filters were soaked for $15 \mathrm{~min}$ in $450 \mathrm{mmol} / \mathrm{L} \mathrm{NaCl}, 45 \mathrm{mmol} / \mathrm{L}$ sodium citrate and for $2-4 \mathrm{~h}$ with shaking at $43^{\circ} \mathrm{C}$ in hybridization mix as described previously (12). ${ }^{32} \mathrm{P}$-labeled probes were denatured at $90^{\circ} \mathrm{C}$ for $5 \mathrm{~min}$ and cooled on ice before use. Hybridizations were carried out at $43^{\circ} \mathrm{C}$ in the hybridization buffer. Hybridized blots were exposed to x-ray film at $-70^{\circ} \mathrm{C}$. Relative quantitation was determined using a Hirshman microdensitometer (Frankfort, Germany).

The probes were removed by incubation overnight in $43^{\circ} \mathrm{C}$ water. They were checked for total removal of the probe by overnight exposure to x-ray film. Those blots showing total removal of the initial probe were then rehybridized to a different labeled cDNA clone.

All results reported here were derived from three independent sets of experiments; each experiment used pooled tissues derived from 3-5 mice. All experiments provided similar results. Student's t-test was used for statistical analysis. The microdensitometric results presented in Table I were derived from those exposures of blots that were within the linear range of the x-ray film. Only blots showing equal amounts of RNA capable of hybridizing to the rRNA probe were used in these experiments. It should be noted that while RNA in these experiments is poly $A+$, there was sufficient contaminating rRNA to detect hybridization following short exposures to labeled pHRR rRNA probe. This control 
permits checks on both RNA loading onto nitrocellulose filters and also on purity of poly A+ RNA preparations used in all experiments.

\section{RESULTS}

Body temperature studies. Litters from $w s t /+$ parents were monitored for rectal temperature beginning at day 18 and ending at the death of the wst/wst littermates (day 28). Results of the temperature patterns of all mice from two different litters are presented in Figures $1 \mathrm{~A}$ and 1B. These results show that near day 22 of age, the body temperatures of the wst/wst mice begin to drop while those of the normal littermates (a mixture of $w s t /+$ and $+1+$ offspring) display only small variations in body temperature during this same timeframe. A difference in body temperature was observed as early as 4-5 days prior to death.

Note that all animals were separated into individual cages at day 18 and therefore were not able to help increase body temperature through "huddling" in the cage.

Gene expression studies. A number of genes have been implicated in the regulation of body temperature $(9,13,14)$. Studies of the expression of some of these transcripts in liver tissues from wst/wst and age-matched control mice were carried out by Northern blot hybridization. Results of blots are evident in Figure 2 and microdensitometric quantitation of some of these blots is presented in Table I. These results show that expression of ornithine amino transferase (OAT; a liver- 
specific marker), proliferating cell nuclear antigen (PCNA), c-fos, and transforming growth factor-beta (TGF- $\beta$ ) transcripts was no different in livers from control and wasted mice. The expression of cytokines IL6 and $\amalg L 1$ and of the apoptosisassociated transcript Rp-8 was approximately twofold higher in wst/wst mice relative to controls, while expression of the acute-phase reactant C-reactive protein-specific transcripts was over 10 -fold higher in wasted mice than in controls. c-jun mRNA was detected in livers from wst/wst mice but not in livers from control mice, demonstrating increased expression of $c-j u n$ in wasted mice relative to controls. The relative increases of expression of c-jun could not be determined because the transcript was undetected in control tissues. The expression of any of these genes in wst/. littermates was not significantly different than was detected in age-matched BCF1 strain-specific controls.

\section{DISCUSSION}

Inappropriate regulation/expression of various cytokines (or extracellular mediators) have been associated with disease and even death in mammals. Abnormal levels of IL6 have been found to be associated with recovery from surgery, rheumatoid arthritis and AIDS (13-16), while IL1 and TNF have been shown to play a role in the progressive wasting, weakness, and anorexia associated with cancer cachexia (17-19). The results reported here demonstrate an increased expression of hepatic mRNA specific for IL1 and IL6 in the wasted mouse relative to controls. The enhanced expression of these two cytokines may be responsible for some of the pathology and symptoms evident in the wasted mouse strain. Since 
both IL1 and IL6 have been shown to function in body temperature regulation (20), the observed temperature decrease in wasted mice may be a direct consequence of increased IL1 and IL6 expression. In addition, the cachexia for which the wasted mice were named may be at least in part attributed to the enhanced levels of ILI mRNA accumulation, which has been shown to affect progressive wasting (17). Recent reports suggest that IL6 may also be involved in cachexia (21). . Both IL1 and TNF may affect total body metabolism, e.g., suppressing lipoprotein lipase activity (17-19); an increase in protein and lipid catabolism might eventually lead to physical wasting or cachexia $(17,18)$.

The overall enhancement of liver c-jun, ILI, and IL6 gene expression reported here and a decrease in albumin gene expression reported by our group previously $(6,7)$ in wasted mice relative to controls suggests that the mouse model is characterized by a reaction similar to the hepatic acute phase reaction. According to current models of this reaction, the IL6 gene product regulates the expression of acute phase plasma proteins (14). Our results demonstrate that the liver expression of C-reactive protein, one of the numerous acute phase reaction proteins, was increased in wasted mice relative to littermate and parental controls. This, as well as the previously reported low albumin expression in the strain $(6,7)$, could be attributed to an IL6 increase. Experiments are underway to determine whether wasted mice in fact undergo a reaction similar to the acute phase reaction in response to physiological stimuli. It remains unclear whether the cascade of events is in response to direct stimuli or is a consequence of some secondary signal(s). The acute phase reaction may be involved in returning the body to 
homeostasis after responding to infection, since the wasted mice are immunocompromised. The pleiotropic nature of IL6 (14-16) also suggests that other cells or tissues in the wasted mouse may be undergoing pathogenesis due to the increased levels of the two cytokines:

Rp-8, IL6, and c-jun transcript induction is associated with the onset of an apoptotic response in a variety of different cell types $(10,20,21)$. Previous work from our group has suggested that wst/wst mice express increased spontaneous apoptosis in lymphocytes relative to controls (Woloschak et al., unpublished information). Experiments are aimed at determining whether hepatocytes from wasted mice are more susceptible to spontaneous or radiation-induced apoptosis than controls. It is interesting that Staphylococcos enterotoxin B, which induces acute phase reactants when administered in vivo, has also been reported to induce apoptosis (22). In addition, a recent report by Soloff et al. (23) has demonstrated induction of the apoptotic response in cultured cells exposed to low temperature conditions. We have not yet established a clear relationship between specific gene induction, thermal dysregulation, and apoptosis, but the wasted mouse model may provide a unique opportunity for such studies.

The c-fos and c-jun gene products make up the AP-1 transcription factor, which regulates cell growth and differentiation. It is interesting that c-jun is expressed at high levels in livers from wasted mice, while c-fos is expressed at control levels. Regulation of these genes is similar, as is regulation of IL6 expression; all three genes share nucleotide similarities in the enhancer region, 
suggesting similar regulatory patterns $(24,25)$. The differences, then, for our observation that c-jun and IL-6 are expressed to high levels in livers from $w s t / w s t$ mice, while c-fos mRNA expression is no different, may be due to a more complex regulatory pattern for c-fos. Several reports have documented that c-fos uses both transcriptional and post-transcriptional regulation for gene expression $(25,26)$.

Recent work from our laboratory has also documented lymphocyte-specific cytokine dysregulation in wasted mice relative to controls $(6,7)$. The work reported here combined with this previous report suggests the presence of overall cytokine dysregulation in wasted mice. 


\section{ACKNOWLEDGEMENTS}

We gratefully acknowledge the following individuals who provided us with cDNA clones: $\alpha$-fetoprotein from S. Tilghman (Princeton University, Princeton, NJ); pHRR rRNA from E. Wieben (Mayo Clinic, MN); Rp-8 from G. P. Owens (Univ. Colorado, Denver, CO); ornithine amino transferase from C. Peraino (Argonne National Laboratory); C-reactive protein from Dr. S. B. Dowton (Washington Univ); PCNA from R. Brava (Bristol Myers); and IL1, IL6, c-jun, c-fos from American type Culture Collection (Rockville, MD). The authors also wish to thank Kay Bexson for excellent secretarial assistance and Drs. Cheryl Denault, Frank Collart, and Tom Seed for critical review of the manuscript.

Work supported by the U.S. Department of Energy, Office of Health and Environmental Research, under Contract No. W-31-109-ENG-38. 
Table I. Expression of mRNA in Liver Transcripts ${ }^{1}$

\begin{tabular}{|c|c|c|c|c|c|c|c|}
\hline $\begin{array}{l}\text { Mouse } \\
\text { Strain }\end{array}$ & OAT & PCNA & $\mathrm{RP}-8$ & IL6 & c-fos & ILI & $\begin{array}{l}\text { C-reactive } \\
\text { protein }\end{array}$ \\
\hline $\mathrm{BCF}_{1}$ & $1.0(.05)^{2}$ & $1.0(.02)$ & $1.0(.10)$ & $1.0(.09)$ & $1.0(.02)$ & $1.0(.05)$ & $1.0(.20)$ \\
\hline wst/. & $0.7(.05)$ & $1.3(.07)$ & $1.1(.15)$ & $1.1(.04)$ & $1.4(.20)$ & $1.1(.08)$ & $1.1(.09)$ \\
\hline$w s t / w s t$ & $1.1(.10)$ & $1.3(.10)$ & $1.8(.20)^{*}$ & $1.8(.01)^{*}$ & $1.1(.07)$ & $2.2(.20)^{*}$ & $9.7(.31)^{*}$ \\
\hline
\end{tabular}

${ }^{1}$ As measured by Northern blot hybridization.

${ }^{2}$ Expression of all transcripts in $\mathrm{BCF}_{1}$ liver was set at 1.0. All other results are expressed relative to that. Values in parentheses are standard ??? of the mean (S.E.M.).

*Statistically different from controls of $p<.05$.

NOTE: Microdensitometric results for c-jun experiments are not presented (Figure 2E) since a hybridization signal was not detected in livers from control mice. 


\section{REFERENCES}

1. Shultz L. D., Sweet H. O., Davisson M. T., and Coman D. R., "Wasted," a new mutant of the mouse with abnormalities characteristic of ataxia telangiectasia. Nature 297, 402-404, 1982.

2. Woloschak G. E., Rodriguez M., and Krco C. J., Characterization of immunologic and neuropathologic abnormalities in "wasted" mice. J Immunol. 138, 2493-2499, 1987.

3. Woloschak G. E., Krco C. J., and Rodriguez M., Influences of the microenvironment on B-cell responses of wasted mice: Comparison of Peyer's patches and mesenteric lymph nodes. Regional Immunol. 1, 163-171, 1988.

4. Tezuke H., Inoue T., Noguti T., Kada T., and Shultz L. D., Evaluation of the mouse mutant "wasted" as an animal model for ataxia telangiectasia. I. Age-dependent and tissue-specific effects. Mutat. Res. 161, 83-90, 1986.

5. Padilla M., Libertin C. R., Krco C. J., and Woloschak G. E., Radiation sensitivity of T-cells from wasted mice. Cell Immunol. 130, 186-194, 1990.

6. Libertin C. R., Ling-Indeck L., Padilla M., and Woloschak G. E., Cytokine and Tcell subset abnormalities in immunodeficient wasted mice. Molec Immunol., in press. 
7. Libertin C. R., Weaver P., Mobarhan S., and Woloschak G. E., (1994) Subnormal albumin gene expression is associated with weight loss in immunodeficient/DNArepair-impaired wasted mice. J. Amer. Assoc. of Nutrition, in press.

8. Papaconstantinou J., Rubeck J. P., and Zhang D., Molecular mechanisms of liverspecific albumin and $\alpha$-fetoprotein gene regulation: review. Develop. Growth $\&$ Differ 32, 205-216, 1990.

9. Bauman H., and Cauldie J., Regulation of hepatic acute phase plasma protein genes by hepatocyte stimulating factors and other mediators of inflammation. Molec. Biol. Med. 7, 147-150, 1990.

10. Owens G. P., Hahn W. E., and Cohen J. J, Identification of mRNAs associated with programmed cell death in immature thymocytes. Molec. Cell. Biol. 8, 4177-4188, 1991.

11. Schwartzman R. A., and Cedlowski J. A., Apoptosis - the biochemistry and molecular biology of programmed cell death. Endocrine Review 14, 133-151, 1993.

12. Woloschak G. E., Liu C-M., Jones P. S., and Jones C. A., Modulation of gene expression in Syrian hamster embryo cells following ionizing radiation. Cancer Res. $50,339-344,1990$. 
13. Wolvekamp M. C. J., and Marquet R. L., Interleukin-6: Historical background, genetics and biological significance. Immunology Letters 24, 1-10, 1990.

14. Morrone G., Ciliberto G., Oliveriero S., Arcone R., and Dente L., Content J, Cortese R. Recombinant IL-6 regulates the transcriptional activation of a set of human acute phase genes. J. Biol. Chem. 263, 12554-12560, 1988.

15. Bairgrie R. J., Lamont P. M., and Morris P. J. The release of interleukin 1ß (IL-1) precedes that of interleukin 6 (IL-6) in patients undergoing major surgery. Lymphokine Cytokine Res. 10, 253-260, 1991.

16. Koj A., Gauldie J., and Baumann H., Biological perspectives of cytokine and hormone networks. In: Acute Phase Proteins, Molecular Biology, Biochemistry, Clinical Applications (Edited by Mackiewicz A., Kushner A. and Bauman H.), p275, CRC Press, Boca Raton, Florida, 1993.

17. Beutler B., and Cerami A., The history, properties, and biological effects of cachectin. Biochemistry 27, 7575-7582, 1988.

18. Philip R., and Epstein L. B., Tumour necrosis factor as immunomodulator and mediator of monocyte cytotoxicity induced by itself, $\gamma$-interferon and interleukin- 1 . Nature 323, 86-89, 1986.

19. Dinarello C. A., Biology of interleukin 1. FASEB J. 2, 108-114, 1988. 
20. Oritani K., Kaisho T., Nakijima K., and Hirano T., Retinoic acid inhibits interleukin-6-induced macrophage differentiation and apoptosis in a murine hematopoietic cell ine, Y6. Blood 80, 2298-2305, 1992.

21. Colotta F., Polentarutti N., Sironi M., and Mantovani A, Expression and involvement of c-fos and c-jun protooncogenes in programmed cell death induced by growth factor deprivation in lymphoid cell lines. J. Biol. Chem. 267, 18278-18283, 1992.

22. Lin Y. S., Lei H. Y., Low T. L., Shen C. L., Chou I. J., and Jan M. S., In vivo induction of apoptosis in immature thymocytes by staphylococcal enterotoxin B. J. Immunol. 149, 1156-1163, 1992.

23. Soloff B. C., Nagle W. A., Moss A. J. Jr., Henle K. J., and Crawford T. T., Apoptosis induced by cold shock in vitro is dependent on cell growth phase. Biochem. Biophys. Res. Commun. 145, 876-883, 1987.

24. Lotem J., and Sachs L., Regulation of leukaemic cells by interleukin 6 and leukaemia inhibitory factor. Ciba Foundation Symposium 167, 80-88, 1992.

25. Wellington C. L., Greenberg M. E., and Belasco J. G., The destabilizing elements in the coding region of c-fos mRNA are recognized as RNA. Molec. Cell. Biol. 13, 5034$5042,1993$. 
26. Edwards D. R., and Mahadevan L. C., Protein synthesis inhibitors differentially superinduce c-fos and c-jun by three distinct mechanisms: Lack of evidence for labile repressors. The EMBO J. 11, 2415-2423, 1992. 
TEMPERATURE $\left({ }^{\circ} \mathrm{C}\right)$
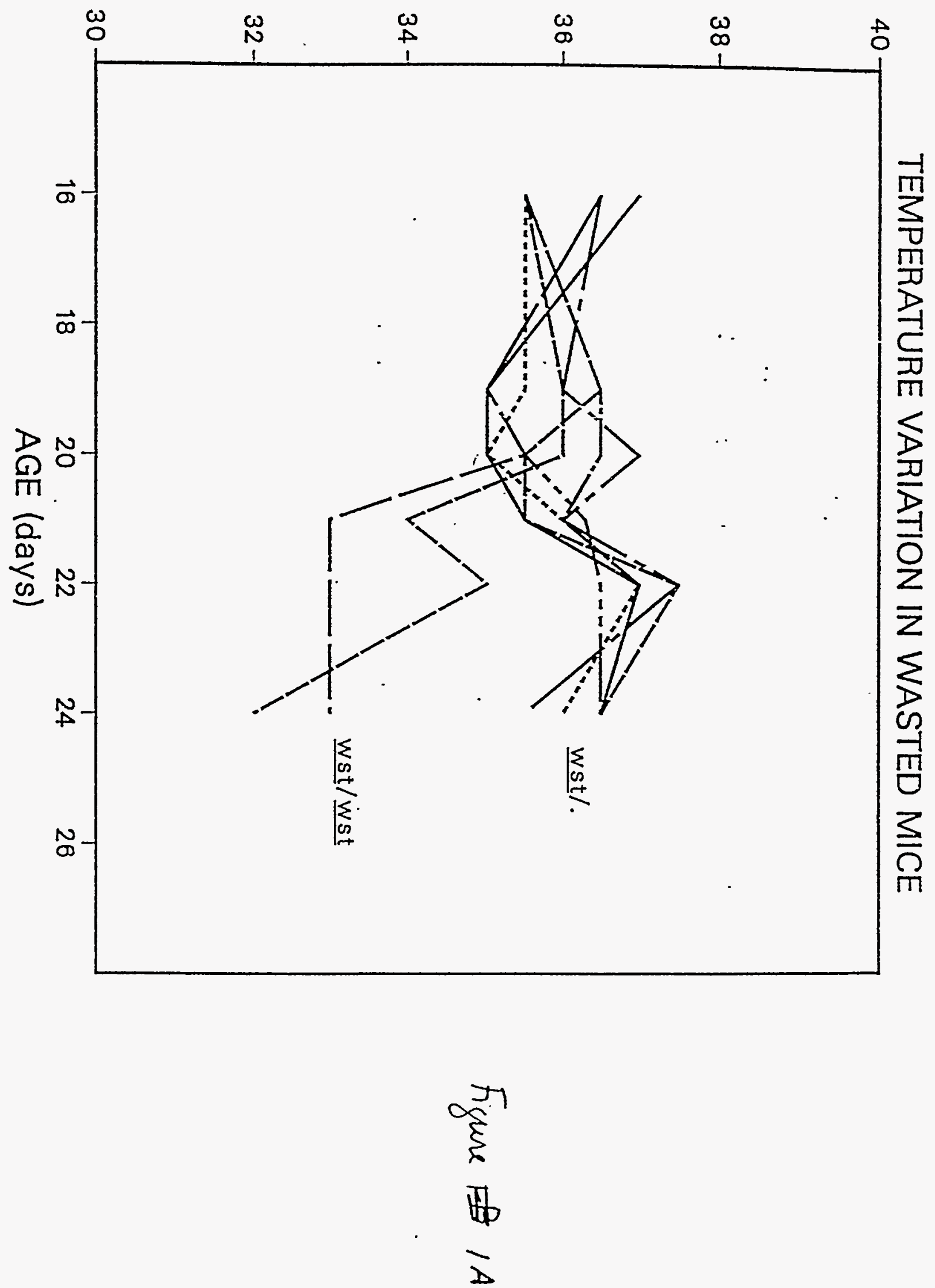


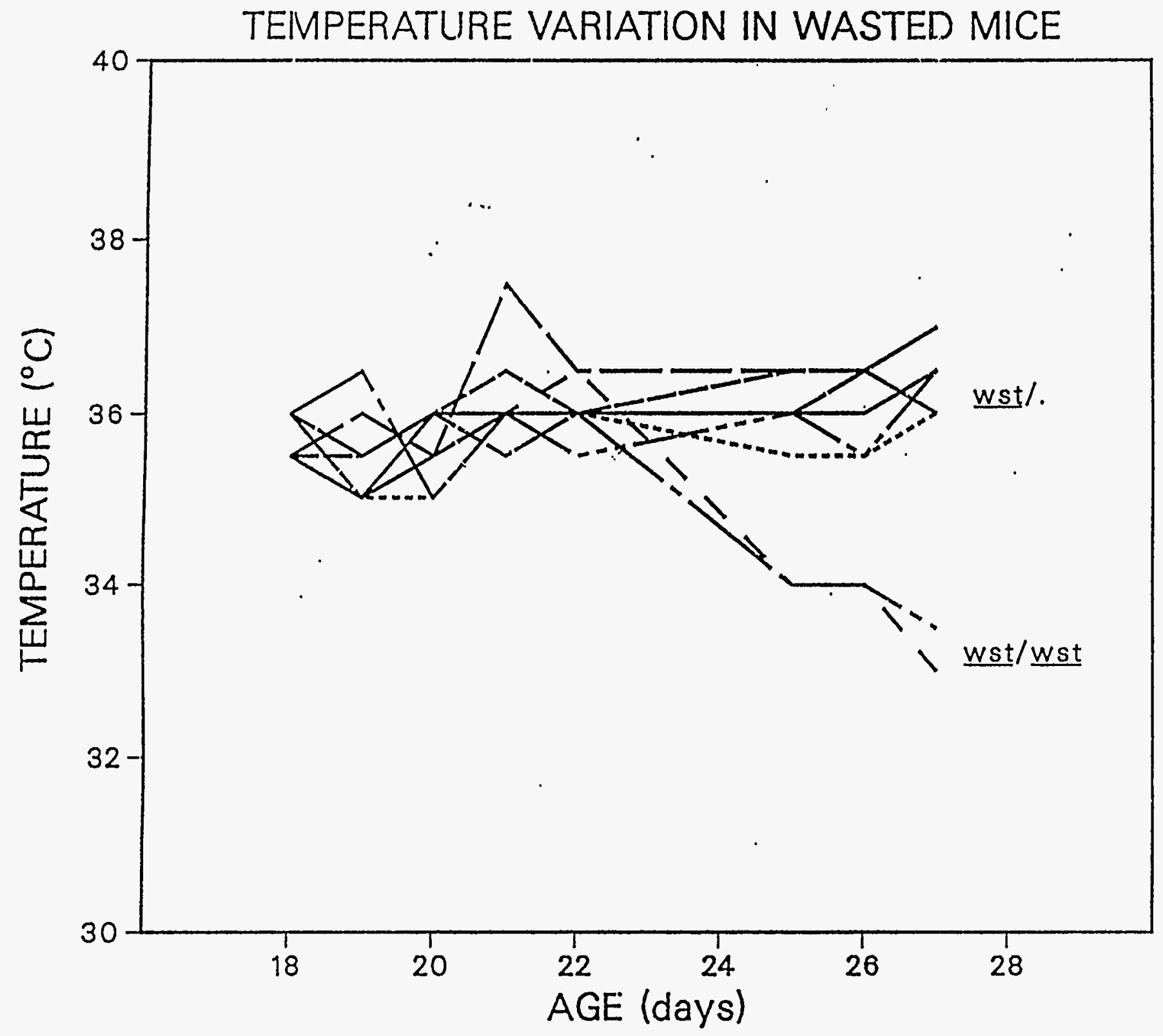

Figure IB 


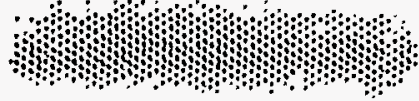

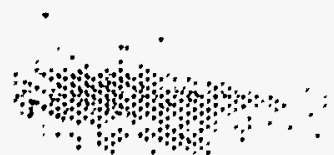

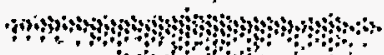
$\therefore$ o ido

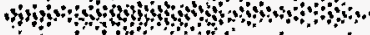

$\because \quad \because \quad \because \quad$ :

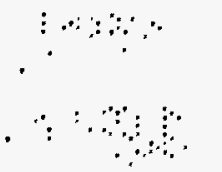

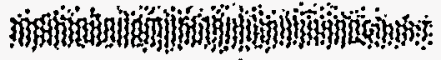

\% :
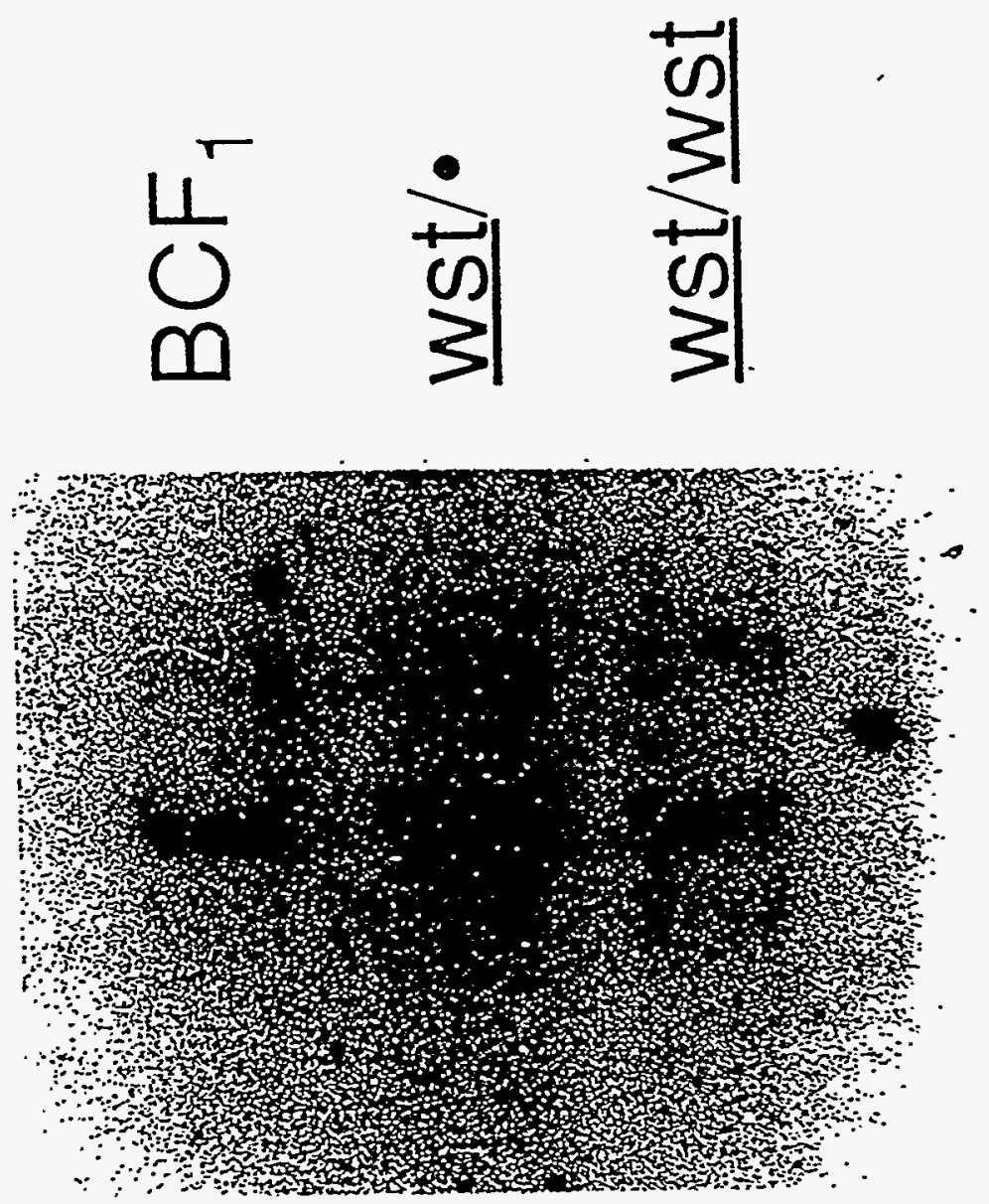

TGF- $\beta$ Liver

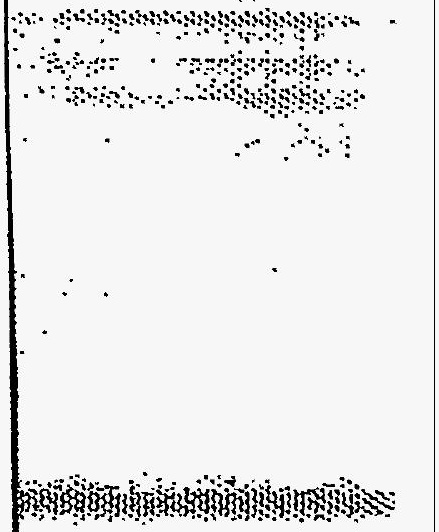

क.

$$
F i g \alpha B
$$


abo

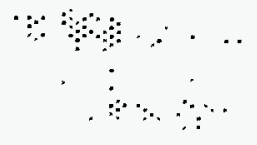

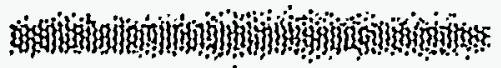

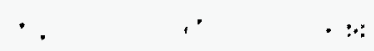

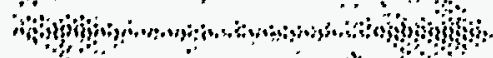

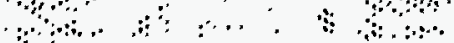

. n n

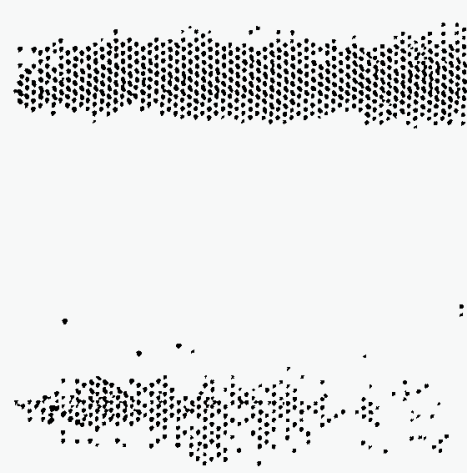

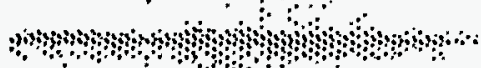
$\therefore$ \% GH

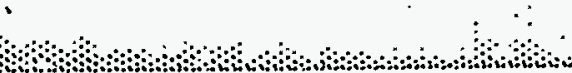

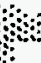

$\therefore$

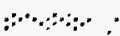




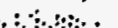

-
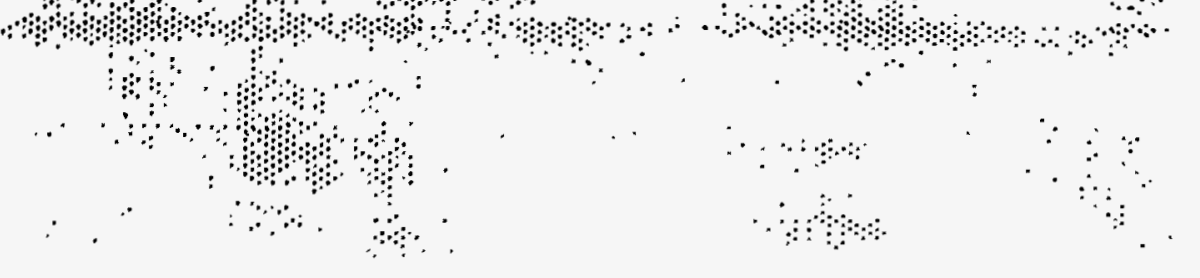

is

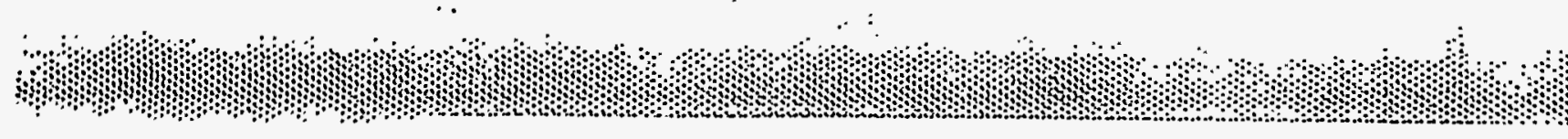

ifis

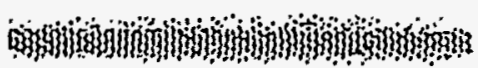

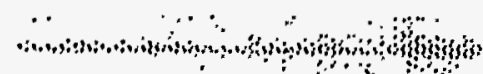
$\because, \cdots \quad \therefore \quad \cdots$

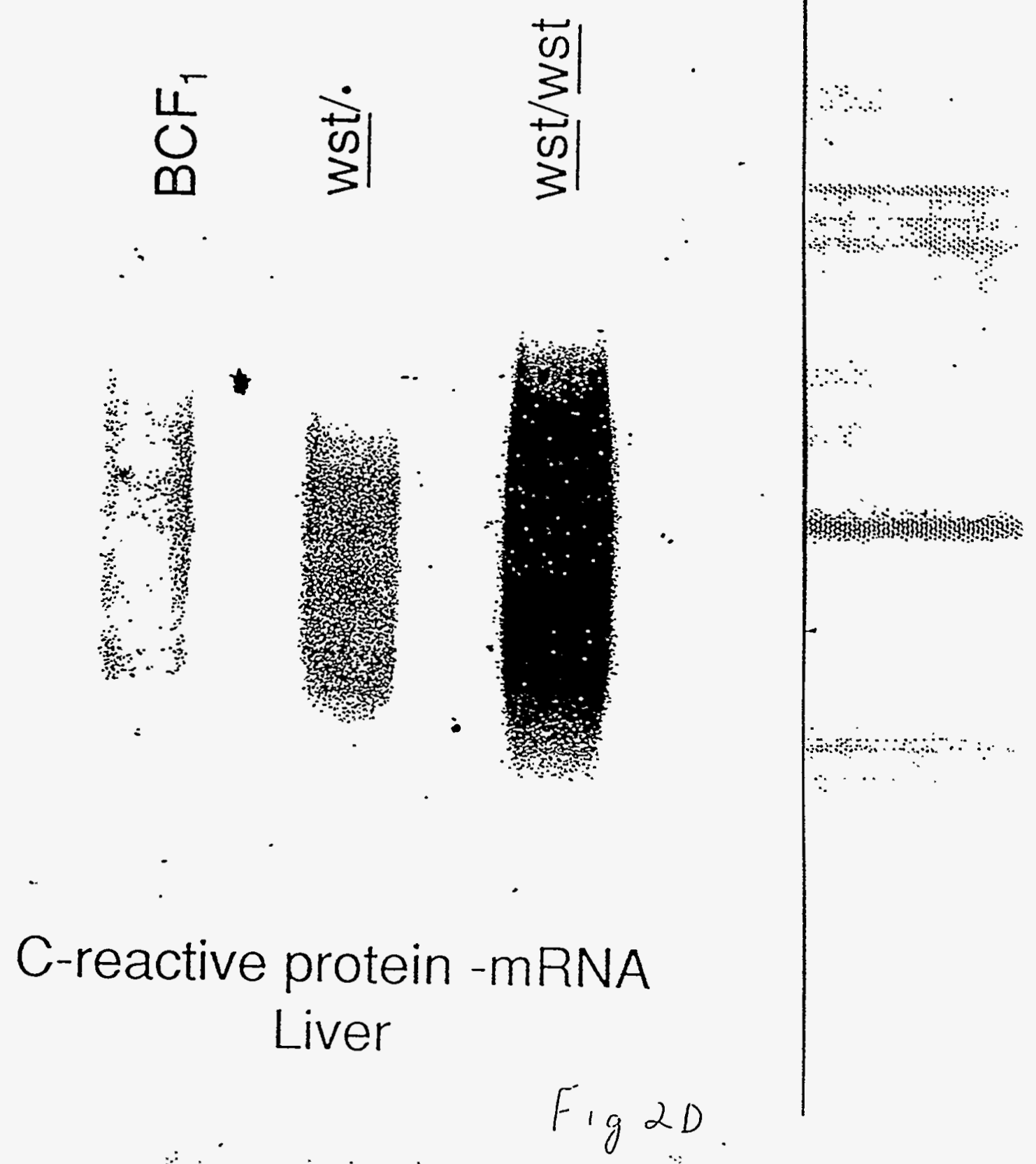

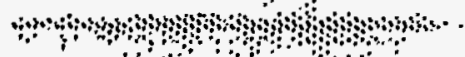
$\because$, काओ : $\because \cdots$

\section{C-reactive protein -mRNA} Liver
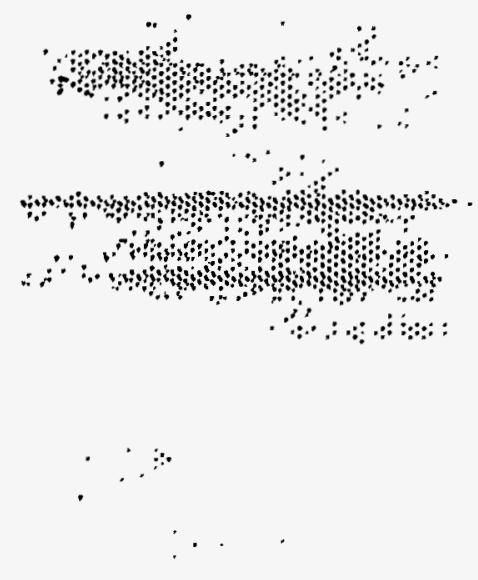

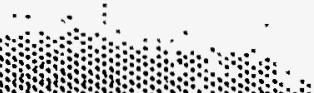



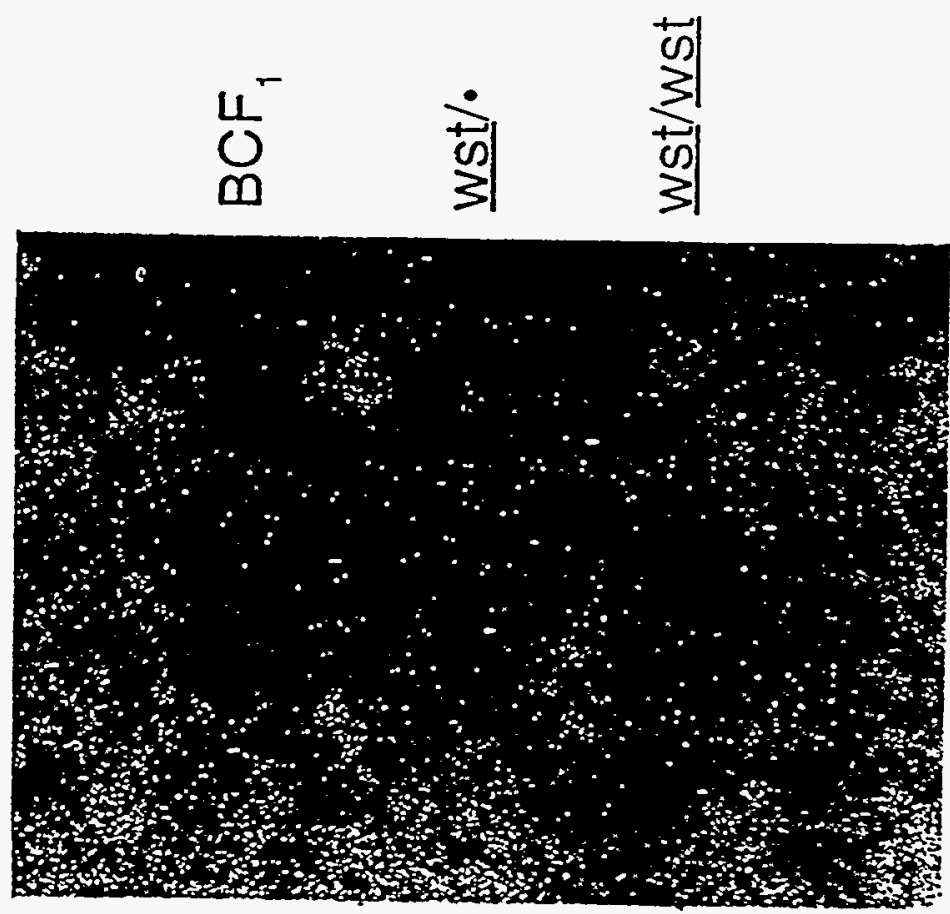

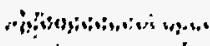

Liver

, ... $\therefore$

c-jun

$$
F, 0, \alpha E
$$

